\title{
HUBUNGAN KADAR SENG SERUM DENGAN TINGGI BADAN ANAK SEKOLAH DASAR PENDERITA GAKY
}

\section{(THE RELATIONSHIP BETWEEN THE LEVEL OF ZINC SERUM AND HEIGHT ON ELEMENTARY SCHOOL CHILDREN WITH GOITER)}

\author{
Nanik Setijowati \\ Laboratorium IImu Kesehatan Masyarakat Fakultas Kedokteran Universitas Brawijaya Malang
}

\begin{abstract}
The incidence goiter starts to the extend in Urban area. Not all Elementary School children with goiter experience of pursued growth. This indicates that besides low iodine content, there are other elements which also influence growth. This research intends to study the relationship between zinc the level of serum and height on elementary school children (8 - 12 year) in endemic goitre areas, in Malang Municipality. Data ware collected with cross-sectional study from August to December 2000. Blood and urine sample of twenty children of each group were examined for zinc serum and iodine urine concentration. Information about diet pattern, socio-economical condition were obtained by structured questionairre for mother and children. This research used Independent T-test, Person Correlation test, and Multiple Regression for statistics analysis. The result showed that: (1). There were significant relationships between energy $(r=0.364, p=0.012)$; protein $(r=0.481, p=0.001)$ and zinc intake $(r=0.491, p=0.001)$ with height; (2). There were significant difference in energy $(p=0.014)$, carbohydrate $(p=0.042)$, lipid $(p=0.014)$, protein $(p=0.003)$, and zinc intake $(p=0.004)$ between the two groups examined. The conclusion was that lower height for age was possibly ascribed to lack of energy, protein, iodine and zinc intake.
\end{abstract}

Key words: zinc serum, iodine urine, height for age, and goiter

\section{PENDAHULUAN}

Program perbaikan gizi Repelita VI bertujuan untuk meningkatkan mutu gizi konsumsi pangan sehingga berdampak pada perbaikan keadaan status gizi masyarakat. Peningkatan status gizi diarahkan pada peningkatan intelektualitas, produktivitas, dan prestasi kerja serta penurunan angka gizi salah terutama gizi kurang. Perbaikan pertumbuhan fisik balita dan anak sekolah merupakan salah satu sasaran program perbaikan gizi masyarakat pada akhir Repelita VI (1).

Upaya perbaikan gizi diprioritaskan untuk menanggulangi masalah gizi kurang yaitu: KEP (Kurang Energi Protein), Anemia Gizi Besi, KVA (Kurang Vitamin A), dan GAKY (Gangguan Akibat Kekurangan Yodium), dengan tetap mengantisipasi timbulnya gejala masalah gizi baru seperti gizi lebih dan defisiensi seng (Zn) (1).Akhir-akhir ini semakin disadari pentingnya tinggi badan, karena gangguan tinggi badan merupakan pertanda dari gangguan gizi kronis atau masa lalu, yang merefleksikan keadaan sosial ekonomi masyarakat (2).

Pada beberapa penelitian, ditemukan adanya penurunan perkembangan mental pada anak pendek, yang

Jurnal Kedokteran Brawijaya, Vol. XXI, No.1, April 2005 Korespondensi: Nanik Setijowati; Lab. IKM-KP Fakultas Kedokteran Unibraw, Jl. Veteran Malang 65145. Telepon: (0341)580993; email: setijowati@fk.unibraw.ac.id kadang-kadang tidak dapat dikembalikan ke dalam keadaan normal (2).

Menjadi pendek pada umur tertentu pada umumnya reversibel selama epifise belum menutup, namun demikian yang paling penting adalah memperhatikan pencegahan hambatan pertumbuhan sejak usia dini (2).

Satu hal yang memprihatinkan ialah bahwa masalah kependekan tubuh (stunted) masih di dapati di kalangan anak sekolah, sebagaimana ditunjukkan di Karanganyar, bahwa sekitar separuh anak adalah pendek, dan semakin tua umur anak cenderung prevalensi kependekannya makin meningkat (3).

Gangguan tumbuh kembang, selain menyebabkan tingginya angka kematian anak, juga menyebabkan berkurangnya potensi belajar dan daya tahan tubuh terhadap penyakit, berkurangnya produktifitas kerja, serta cenderung lebih mudah menderita penyakit kronis dikemudian hari (4).

Berdasarkan hasil survey prevalensi gondok endemik di Kota Malang, yang dilakukan pada tahun 1998, Desa Bumiayu Kecamatan Kedungkandang menempati urutan tertinggi dengan TGR (Total Goitre Rate) sebesar 47,41\% dibandingkan 15 desa lainnya. Dan pada tahun 1999, Kecamatan Kedungkandang tetap menempati urutan tertinggi dengan TGR sebesar 26,1\%. Sekilas dari tahun ke tahun prevalensi gondok endemik di Kota Malang terjadi penurunan, tetapi sayangnya tidak disertai dengan data anak sekolah yang mengalami hambatan pertumbuhan. 
Menurut lyengar (1988), wilayah dengan gondok endemik biasanya disertai dengan terbatasnya trace elemen lainnya, sehingga tidak menutup kemungkinan adanya unsur lain yang berpengaruh terhadap pertumbuhan disamping unsur yodium (5).

Sejauh ini di Indonesia masih belum banyak penelitian yang secara spesifik mengungkap keterkaitan antara seng dengan yodium terhadap pertumbuhan tinggi badan. Kalaupun dilakukan hanya terbatas pada salah satu kajian, seng atau yodium saja.

Bertolak dari hal tersebut di atas, maka tujuan umum penelitian ini adalah untuk mempelajari kaitan antara kadar seng serum dan yodium urine terhadap perbedaan tinggi badan anak Sekolah Dasar penderita GAKY, agar didapatkan gambaran bahwa gabungan unsur seng dan yodium berpengaruh terhadap pertumbuhan tinggi badan, atau hanya salah satu unsur saja yang berpengaruh.

\section{METODE}

Penelitian ini dilakukan secara crossectional, di Desa Bumiayu, Kecamatan Kedungkandang, Kota Malang.

Terdapat 2 kelompok sampel yaitu: kelompok dengan status gizi baik/sedang dan kelompok dengan status gizi kurang/ buruk berdasarkan Tinggi Badan/Umur (TB/U), yang masing-masing terdiri dari anak Sekolah Dasar, usia 8 - 12 tahun, belum akil baliq, mempunyai gondok positif, dan bertempat tinggal di Desa Bumiayu. Orang tua dari anak yang bersangkutan juga menjadi anggota sampel. Pada kedua kelompok digunakan tehnik simple random sampling.

Pengumpulan data dilakukan dengan menggunakan kuesioner untuk mengetahui identitas responden dan keluarga terutama tentang pendidikan dan pekerjaan orang tua, konsumsi makanan baik kuantitas maupun kualitas, serta untuk mendapatkan data pola makan keluarga dan anak. Tehnik wawancara sekaligus pengumpulan bahan makanan pokok dan air dilakukan dari rumah ke rumah.

Penentuan status gizi berdasarkan TB/U menggunakan nilai Z-score menurut baku WHO-NCHS. Adapun kriteria status gizi sebagai berikut: (6).

a). Baik, bila "batas bawah" lebih besar atau sama dengan -1 SD $(\geq-1 S D)$.

b). Sedang, bila "batas bawah" lebih besar atau sama dengan -2 SD dan "batas atas" lebih kecil -1 SD (-2 SD $\leq \mathrm{x}<-1 \mathrm{SD}$ ).

c). Kurang, bila "batas bawah" lebih besar atau sama dengan -3 SD dan "batas atas" lebih kecil -2 SD (-3 SD $\leq \mathrm{x}<-2 \mathrm{SD})$. d). Buruk, bila "batas atas" lebih kecil -3 SD (<-3 SD). Dengan rumus skor

$\mathrm{SD} T B / \mathrm{U}(\mathrm{x})=\underline{\text { nilai hasil pengukuran }- \text { median }}$ $+1 \mathrm{SD}$ - median

Untuk selanjutnya TB/U dibagi dua bagian dengan cut off point -2SD.

Sedangkan pengambilan darah untuk pemeriksaan kadar seng (Zn) serum anak dikerjakan di sekolah, dengan menggunakan spuit, diambil $2 \mathrm{cc}$ darah dari vena cubitus (lipatan lengan), kemudian pada spuitnya diberi label, disimpan dalam termos es, untuk selanjutnya dikirim ke Laboratorium Farmakologi Fakultas Kedokteran Unibraw Malang. Untuk meminimalkan variasi kadar seng serum, maka dilakukan pengambilan darah pada pagi hari sebelum sarapan pagi. Pemeriksaan dilakukan dengan menggunakan alat Flame Fotometer. Penentuan kadar seng serum berdasarkan angka kecukupan seng (Zn) rata-rata yang dianjurkan per orang per hari ( $>60 \mu \mathrm{g} / \mathrm{dl}$ ) dengan kategori status sebagai berikut: (7).
a) Normal $:>60 \mu \mathrm{g} / \mathrm{dl}$.
b) Defisiensi ringan : $40-60 \mu \mathrm{g} / \mathrm{dl}$.
c) Defisiensi berat : $<40 \mu \mathrm{g} / \mathrm{dl}$.
Untuk pemeriksaan kadar yodium urine dilakukan pengambilan urine kurang lebih $30 \mathrm{cc}$, kemudian dimasukkan ke dalam botol kecil setelah diberi larutan phenol secukupnya. Sesudah diberi label, botol-botol tersebut kemudian dikirim ke Laboratorium Farmakologi Fakultas Kedokteran Universitas Brawijaya Malang. Adapun metode yang digunakan adalah metode pemeriksaan kadar yodium urine dengan menggunakan alat Spectrometer Model A (8).

Adapun berat ringannya kejadian GAKY dapat diklasifikasikan memakai standard WHO sebagai berikut: 1. Ringan, apabila kadar yodium urine antara 50 - $99 \mu \mathrm{g} / \mathrm{I}$. 2. Sedang, apabila kadar yodium urine antara $20-49 \mu \mathrm{g} / \mathrm{l}$. 3. Berat, apabila kadar yodium urine $<20 \mu \mathrm{g} / \mathrm{l}(9)$.

Analisa data dilakukan dengan cara deskriptif dan analitik (uji t-test independent dan korelasi pearson), dengan derajat kepercayaan $95 \%, a=0,05$, bermakna, bila $p<0,05$, menggunakan komputer program SPSS for window versi 10 .

\section{HASIL PENELITIAN}

Data yang diperoleh pada penelitian ini ditabulasi sebagai berikut: 
Tabel 1. Distribusi Responden Menurut Pola Makan Keluarga Sehari-hari di Desa Bumiayu, Kecamatan Kedungkandang, Kota Malang, Tahun 2000

\begin{tabular}{llcccc}
\hline \multirow{2}{*}{ No. } & \multicolumn{1}{c}{ Pola Konsumsi } & \multicolumn{2}{c}{ TB/U (Normal) } & \multicolumn{2}{c}{ TB/U (Kurang) } \\
\cline { 3 - 6 } & Nasi + lauk pauk & $\mathbf{n}$ & $\%$ & $\mathbf{n}$ & $\%$ \\
\hline 1. & Nasi + sayur & 2 & 20 & 11 & 55 \\
2. & 13 & 65 & 4 & 20 \\
3. Nasi + lauk-pauk + sayur & 1 & 5 & 5 & 25 \\
4. & Nasi + lauk-pauk + buah & - & - & - & - \\
5. Nasi + sayur + buah & - & - & - & - \\
6. Nasi + lauk-pauk + sayur + buah & - & - & - & - \\
7. & Nasi + lauk-pauk + sayur + buah + susu & 20 & 100 & 20 & 100 \\
\hline \multicolumn{2}{c}{ Total } & & & &
\end{tabular}

Tabel 2. Distribusi Responden Menurut Penghasilan Orang Tua di Desa Bumiayu, Kecamatan Kedungkandang, Kota Malang, Tahun 2000

\begin{tabular}{|c|c|c|c|c|c|c|c|c|c|}
\hline \multirow{3}{*}{ No. } & \multirow{3}{*}{ Penghasilan/ Bulan (Rp.) } & \multicolumn{4}{|c|}{ TB/U (Normal) } & \multicolumn{4}{|c|}{ TB/U (Kurang) } \\
\hline & & \multicolumn{2}{|c|}{ Ayah } & \multicolumn{2}{|c|}{ Ibu } & \multicolumn{2}{|c|}{ Ayah } & \multicolumn{2}{|c|}{ Ibu } \\
\hline & & $\mathrm{n}$ & $\%$ & $\mathrm{n}$ & $\%$ & $n$ & $\%$ & $\mathrm{n}$ & $\%$ \\
\hline 1. & $<200.000$ & 3 & 15 & 6 & 30 & 6 & 30 & 5 & 25 \\
\hline 2. & $200.000-300.000$ & 9 & 45 & 4 & 20 & 12 & 60 & 4 & 20 \\
\hline 3. & $300.001-400.000$ & 4 & 20 & 1 & 5 & - & - & - & - \\
\hline 4. & $>400.000$ & 3 & 15 & - & - & 1 & 5 & - & - \\
\hline 5. & Tidak Ada & 1 & 5 & 9 & 45 & 1 & 5 & 11 & 55 \\
\hline & Total & 20 & 100 & 20 & 100 & 20 & 100 & 20 & 100 \\
\hline
\end{tabular}

Tabel 3. Distribusi Responden Menurut Jumlah Anak Kandung di Desa Bumiayu, Kecamatan Kedungkandang, Kota Malang, Tahun 2000

\begin{tabular}{cllcccc}
\hline \multirow{2}{*}{ No. } & \multirow{2}{*}{ Jumlah Anak } & \multicolumn{2}{c}{ TB/U (Normal) } & \multicolumn{2}{c}{ TB/U (Kurang) } \\
\cline { 3 - 6 } & & $\mathbf{n}$ & $\%$ & $\mathbf{n}$ & $\%$ \\
\hline 1. & Satu & & 1 & 5 & 1 & 5 \\
2. & Dua & 6 & 30 & 6 & 30 \\
3. & Tiga & & 4 & 20 & 1 & 5 \\
4. & $>$ Tiga & & 9 & 45 & 12 & 60 \\
\hline & & Total & 20 & 100 & 20 & 100 \\
\hline
\end{tabular}

Keterangan: $n=$ jumlah

$\%=$ persen

Tabel 4. Distribusi Responden Menurut Konsumsi Energi, Karbohidrat, Lemak, Protein dan Seng di Desa Bumiayu, Kecamatan Kedungkandang, Kota Malang, Tahun 2000

\begin{tabular}{clcccccc}
\hline \multirow{2}{*}{ No. } & \multirow{2}{*}{ Jenis Zat Gizi (Satuan) } & \multicolumn{3}{c}{ TB/U (Normal) } & \multicolumn{3}{c}{ TB/U (Kurang) } \\
\cline { 3 - 7 } & & Rata-rata & SD & \% RDA & Rata-rata & SD & \% RDA \\
\hline 1. & Energi (Kkal) & 1444 & 314 & 68 & 1185 & 244 & 53 \\
2. & Karbohidrat (gram) & 230 & 50 & 75 & 193 & 53 & 60 \\
3. & Lemak (gram) & 35 & 10 & 52 & 27 & 7 & 35 \\
4. & Protein (gram) & 40 & 12 & 123 & 29 & 6 & 110 \\
5. & Seng (mg) & 0,38 & 0,09 & 2,4 & 0.29 & 0,05 & 2,4 \\
\hline
\end{tabular}

Keterangan: RDA = Recommended Dietary Allowance 


\section{DISKUSI}

Pada frekuensi distribusi pola makan keluarga (Tabel 1), ternyata sekitar $65 \%$ dari responden dengan status gizi baik/ sedang sudah mempunyai pola konsumsi gizi seimbang meskipun belum lengkap, sedangkan sekitar $55 \%$ pada responden dengan status gizi kurang/ buruk masih belum seimbang, karena sayur yang banyak mengandung vitamin dan mineral jarang dikonsumsi. Namun demikian, dari data pola konsumsi makanan keluarga, pada umumnya kedua kelompok tersebut sebagian besar mengkonsumsi bahan makanan nabati, di mana pada anak dengan status gizi baik/ sedang kuantitasnya lebih banyak, sedangkan sumber protein hewani jarang dikonsumsi oleh kedua kelompok.

Dari segi penghasilan keluarga (Tabel 2), ternyata sebesar $35 \%$ pada status gizi baik/ sedang mempunyai penghasilan perbulan lebih dari Rp. $300.000,-$, sedangkan pada statis gizi kurang/ buruk hanya $5 \%$ saja, walaupun kedua kelompok ini hampir sama dalam tingkat pendidikan orang tua yang sebagian besar adalah setingkat sekolah dasar.

Demikian juga pada orang tua dengan jumlah anak kandung yang lebih dari tiga (Tabel 3), ternyata menunjukkan bahwa jumlah anak dengan status gizi baik/sedang sebesar $45 \%$, sedangkan pada anak dengan status gizi kurang/ buruk jauh lebih banyak sebesar $60 \%$.

Melihat dari frekuensi distribusi pola makan keluarga, penghasilan, dan jumlah anak, tampaknya keadaan ini mungkin sebagai penyebab perbedaan status gizi berdasarkan TB/U. Tentunya hal ini tidak terlepas dari faktor-faktor yang berpengaruh lainnya, misalnya faktor genetik.

Walaupun demikian tetap ditekankan dalam hal ini, bahwa asupan dan absorbsi yang tidak adekuat, pengeluaran berlebihan, atau penggunaan yang meningkat dari zat gizi akan banyak pengaruhnya terhadap perbedaan TB/U.

Pada analisa statistik dari uji t-test independent menunjukkan bahwa tidak ada beda secara bermakna kadar seng serum antara status gizi baik/ sedang dan status gizi kurang/ buruk berdasarkan TB/U $(p=0,14)$, Walaupun demikian, ada beda secara bermakna asupan seng terhadap perbedaan status gizi berdasarkan TB/U $(p=0,004)$.

Bila dilihat rata-rata asupan seng, ternyata pada status gizi baik/ sedang lebih tinggi, yaitu 0,38 $\pm 0,09 \mathrm{mg}$ daripada status gizi kurang/ buruk sebesar $0,29 \pm 0,05 \mathrm{mg}$, tetapi keadaan tersebut masih jauh dari angka kecukupan gizi yang dianjurkan (RDA) untuk seng sebesar $10-15 \mathrm{mg} /$ hari.

Disamping rendahnya asupan seng, komponen makanan tampaknya berperan penting terhadap bioavailabilitas seng, karena adanya interaksi antara seng dan komponen makanan lainnya, seperti fitat (inositol heksafosfat), besi, kalsium, dan serat yang akan menghambat absorbsi seng, di mana pada status gizi baik/ sedang maupun status gizi kurang/ buruk, lebih banyak mengkonsumsi makanan kaya fitat dengan sedikit protein hewani.

Selain itu, sejumlah data yang ada mengenai seng menunjukkan bahwa pada hewan dan manusia, kadar seng dipertahankan dalam kisaran yang sangat sempit, dan dari berbagai studi kinetika mengungkapkan bahwa seng yang baru diserap secara cepat akan diangkut dari kompartemen plasma ke jaringan lain, terutama pada hati (10).

Keadaan inilah yang mungkin menyebabkan kadar seng serum tidak berbeda secara bermakna, antara ratarata kadar seng serum pada status gizi baik/ sedang sebesar 4,58 $\pm 1,32 \mu \mathrm{g} / \mathrm{dl}$ dan pada status gizi kurang/ buruk sebesar 3,95 $\pm 1,40 \mu \mathrm{g} / \mathrm{dl}$.

Meskipun pengambilan darah untuk pemeriksaan seng serum dilakukan pada waktu pagi hari sebelum sarapan, ternyata rata-rata kadar seng serum tersebut jauh dari normal (>60 $\mu \mathrm{g} / \mathrm{dl})(7)$, dan termasuk defisiensi berat. Walaupun demikian, secara klinis belum ada tanda-tanda defisiensi berat. Pada beberapa literatur dikatakan, bahwa cara terbaik untuk menilai kemungkinan defisiensi seng adalah penafsiran hasil konsentrasi seng dilakukan bersamaan dengan keadaan klinis, metabolik, serta melakukan pemantauan respon fisik maupun biokimia terhadap suplementasi seng (11).

Pada keadaan defisiensi seng yang berat, konsentrasinya dalam plasma kemungkinan tidak mengalami penurunan, akibat adanya proses katabolisme jaringan, terutama katabolisme otot untuk membebaskan seng dalam mendukung sintesa protein yang penting. Apalagi pada anak usia 8 - 12 tahun, dimana sintesa protein sangat diperlukan untuk proses pertumbuhan $(11,12)$.

Bila dilihat dari asupan seng yang sangat rendah, bisa dipastikan bahwa tubuh menyesuaikan kebutuhan seng dengan mengubah seng endogen $(11,13,14)$. Tetapi pada kenyataannya kadar seng serum rata-rata sangat rendah. Hal ini mungkin bisa disebabkan adanya suatu kemampuan yang tinggi untuk mendistribusikan kembali seng ke beberapa jaringan yang paling memerlukan (15).

Namun demikian, sebaiknya mulai dipikirkan untuk memberikan suplementasi $\mathrm{ZnSO}_{4}$ dengan harga relatif lebih murah dibandingkan protein hewani yang jarang dikonsumsi. Pemberian ini dimaksudkan untuk memperbaiki asupan seng yang sangat rendah, agar tidak terus menerus mempergunakan seng endogen.

Disamping itu, pada analisa statistik dari uji t-test independent menunjukkan bahwa tidak ada beda secara bermakna kadar yodium urine antara status gizi baik/ sedang dan status gizi kurang/ buruk berdasarkan TB/U ( $p$ $=0,081$. .

Menurut literatur, yodium urine menggambarkan cukup tidaknya asupan yodium, baik dari makanan, minuman maupun dalam bentuk lainnya, karena dua pertiga 
yodida yang dimakan pada keadaan normal akan dibuang melalui urine (16).

Dari hasil data pola konsumsi makanan keluarga dengan status gizi baik/ sedang maupun status gizi kurang/ buruk, pada umumnya sebagian besar mengkonsumsi bahan makanan nabati dengan kuantitas dan frekuensi yang cukup besar, sedangkan bahan makanan hewani, termasuk ikan laut kuantitas dan frekuensinya relatif kecil. Keadaan inilah yang mungkin menyebabkan kadar yodium urine tidak berbeda secara bermakna, karena seperti diketahui ikan laut mengandung yodium yang cukup besar.

Adapun rata-rata kadar yodium urine pada status gizi baik/ sedang maupun status gizi kurang/ buruk, berturutturut sebesar 0,43 $\pm 0,08 \mu \mathrm{g} / \mathrm{l}$ dan 0,48 $\pm 0,08 \mu \mathrm{g} / \mathrm{l}$, dengan nilai median $0,45 \mu \mathrm{g} / \mathrm{l}$ dan $0,48 \mu \mathrm{g} / \mathrm{l}$. Jika hasil ini dibandingkan dengan nilai batas normal kadar yodium urine sebesar $>100 \mu \mathrm{g} / \mathrm{l}$ (9), maka keduanya termasuk defisiensi berat. Keadaan ini tampaknya sudah berlangsung lama, sehingga keduanya mengalami pembesaran kelenjar gondok untuk mempertahankan laju metabolisme basal normal.

Karena yodium urine merupakan salah satu cara untuk menilai lodine Deficiency Disorder (IDD), disamping palpasi, USG, maupun kadar TSH, maka keadaan ini termasuk kritis, perlu secepatnya dikoreksi (8). Tetapi pada kenyataannya, tidak ditemukan anak kretin di lapangan.

Walaupun demikian, pada daerah endemik sedang maupun berat perlu diberikan suplementasi kapsul beryodium (1), tetapi hingga tiga tahun terakhir anak-anak Sekolah Dasar didaerah tersebut tidak pernah mendapatkan kapsul beryodium.

Pada analisa statistik korelasi pearson, tampak tidak ada hubungan yang bermakna antara kadar seng serum dengan status gizi berdasarkan TB/U $(r=0,243 ; p=0,076)$. $\mathrm{Hal}$ ini mungkin bisa disebabkan kedua kelompok mempunyai asupan seng yang sangat rendah dan seng endogen secepatnya dipergunakan oleh jaringan penerima seng yang sama, yaitu kelenjar thyroid dengan prioritas tinggi.

Sebaliknya ada hubungan yang bermakna antara asupan energi dengan status gizi berdasarkan TB/U ( $r=$ $0,364, p=0,012$ ), antara asupan protein dengan status gizi berdasarkan TB/U $(r=0,481, p=0,001)$, dan antara asupan seng dengan status gizi berdasarkan TB/U $(r=0,491, p=$ $0,001)$.

Disamping itu ada beda nyata asupan energi $(p=$ $0,014)$, karbohidrat $(p=0,042)$, lemak $(p=0,014)$, protein ( $p$ $=0,003)$ maupun seng $(p=0,004)$ antara status gizi baik / sedang maupun status gizi kurang/ buruk. Adapun asupan rata-rata energi, karbohidrat, lemak, protein dan seng antara status gizi baik/ sedang maupun status gizi kurang/ buruk dapat dilihat pada Tabel 4 beserta prosentase masing-masing terhadap RDA-nya.
Dari kenyataan tersebut di atas dapat dijelaskan, karena kelenjar thyroid mengalami defisiensi yodium disamping defisiensi seng, maka jaringan ini mendapat prioritas tinggi untuk menerima seng. Apabila seng asupan sangat rendah, maka seng endogen yang akan dipakai (15).

Akibatnya fungsi tiroksin berjalan normal, yang sekresinya dari kelenjar thyroid diatur melalui mekanisme umpan balik spesifik hipotalamus ( $\mathrm{TRH}=$ Thyrotropin Releasing Hormon) dan hipofise anterior ( $\mathrm{TSH}=$ Thyroid Stimulating Hormon). Tetapi karena mengalami defisiensi yodium, maka terjadi penurunan produksi hormon thyroid $\left(T_{4}\right)$. Bila kadar $\left(T_{4}\right)$ dalam darah menurun, akan merangsang peningkatan sekresi TSH dengan meningkatkan aktifitas sel thyroid yang menyebabkan hiperplasia thyroid. Mungkin hal ini dapat menjelaskan tidak adanya hubungan secara bermakna antara kadar yodium urine dengan status gizi berdasarkan TB/U ( $r=-0,181$ dan $p=0,145)$.

Tiroksin meningkatkan kecepatan metabolisme semua sel, dan sebagai akibatnya secara tidak langsung mempengaruhi metabolisme protein. Bila karbohidrat dan lemak kurang tersedia untuk energi, tiroksin menyebabkan degradasi protein dengan cepat untuk digunakan sebagai energi. Sebaliknya, bila karbohidrat dan lemak terdapat dalam jumlah yang adekuat, dan juga tersedia asam amino dalam jumlah berlebihan di cairan ekstrasel, tiroksin dapat meningkatkan kecepatan sintesa protein (16). Selama hormon thyroid cukup dalam tubuh, maka pengaruh hormon pertumbuhan dari hipofise terhadap efek pertumbuhan menjadi bermakna.

Walaupun sumbangan energi yang diberikan oleh karbohidrat dan lemak hampir sama antara status gizi baik/ sedang maupun status gizi kurang/ buruk, berturut-turut sebesar $64 \%$ dan 22\%; serta 65\% dan 20\% (lihat Tabel 4), tampaknya prosentase terhadap RDA untuk masingmasing asupan (energi, karbohidrat, lemak, protein, kecuali seng) jauh lebih tinggi pada status gizi baik/ sedang daripada status gizi kurang/ buruk. Sedangkan prosentase terhadap RDA untuk seng pada kedua kelompok memang sama, tetapi rata-rata asupan seng jauh lebih besar pada status gizi baik/ sedang daripada status gizi kurang/ buruk..

Hal inilah yang mungkin sebagai penyebab adanya perbedaan status gizi berdasarkan TB/U, sehingga status gizi berdasarkan TB/U berkorelasi secara bermakna dengan asupan energi, protein maupun seng.

Keadaan ini sesuai dengan tulisan Brown EJ (17), bahwa tulang secara perlahan-lahan dan terus-menerus mengalami proses perbaikan dan pergantian yang dikenal sebagai "remodeling". Selama remodeling, matriks protein tua diganti dengan sintesa protein baru dan mineralnya di daur ulang, sedangkan suplai zat gizi yang terus menerus diperlukan untuk menyokong aktivitas sel tulang dalam pembentukan dan mempertahankan jaringan tulang. 
Karena proses pertumbuhan tulang tidak terlepas dari adanya sintesa protein, dan hormon tiroksin dapat disekresi secara normal oleh kelenjar thyroid walaupun terjadi hiperplasia, maka sintesa protein masih dapat berjalan secara normal. Keadaan ini terjadi apabila energi yang disumbang oleh karbohidrat maupun lemak masih mencukupi. Sedangkan seng endogen segera keluar dari plasma menuju kelenjar thyroid yang menjadi prioritas. Hal ini mungkin dapat menjelaskan tidak adanya hubungan yang bermakna antara kadar seng serum dan yodium urine terhadap TB/U ( $F=1,544$, dan $p=0,228)$.

Disamping itu, tidak adanya hubungan yang bermakna antara kadar seng serum dengan asupan seng $(r$ $=0,175$, dan $p=0,153)$; dengan asupan energi $(r=0,026$ dan $p=0,439)$; dan dengan asupan protein $(r=-0,017$, dan $p=0,460$ ) menunjukkan bahwa tubuh melakukan efisiensi terhadap defisiensi seng dengan memanfaatkan sebesarbesarnya asupan seng dan seng endogen untuk proses metabolisme dan sintesa protein.

Dari pembahasan diatas tampak bahwa rendahnya TB/U lebih banyak dikarenakan rendahnya masukan kalori dan mungkin juga protein, yang tentunya ditunjang dengan rendahnya konsumsi yodium dan seng.

Keadaan ini yang perlu menjadi pertimbangan, bahwa dalam mengoreksi GAKY dan akibatnya (termasuk pengaruhnya terhadap tinggi badan) selain perlu suplementasi double micronutrient (yodium dan seng) juga perlu diperhatikan status gizi awalnya (cukup atau tidaknya konsumsi kalori dan protein).
Pemberian suplementasi tersebut tampaknya baru akan berhasil apabila diberikan pada penderita dengan konsumsi kalori dan protein yang cukup pula.

\section{KESIMPULAN}

Dari hasil penelitian di atas dapat disimpulkan bahwa: rendahnya TB/U lebih banyak dikarenakan rendahnya masukan kalori dan mungkin juga protein, yang tentunya ditunjang dengan rendahnya konsumsi yodium dan seng. Berdasarkan keadan tersebut dapat dipertimangkan, bahwa dalam mengkoreksi GAKY dan akibatnya (termasuk pengaruhnya terhadap tinggi badan) selain perlu suplementasi double micronutrient (yodium dan seng) juga perlu diperhatikan status gizi awalnya (cukup atau tidaknya konsumsi kalori dan protein).

\section{SARAN} GAKY:

Bagi Penentu Kebijakan program penanggulangan

1.Perlu meningkatkan strategi pemberian penyuluhan pada masyarakat tentang bahan makanan yang kaya akan kandungan zat gizi mikronutrient seng dan yodium, serta penggunaan garam beryodium dengan benar.

2. Perlu memberikan suplementasi $\mathrm{ZnSO}_{4}$ dan kapsul beryodium pada daerah endemik GAKY.

3. Perlu dipertimbangkan pentingnya suplementasi mikronutrient (yodium dan atau seng pada waktu penderita GAKY dalam kondisi status gizi baik (cukup konsumsi kalori dan protein).

\section{DAFTAR KEPUSTAKAAN}

1. Kodyat B. Penuntasan Masalah Gizi Utama (Posisi Repelita VI, Kebijaksanaan dan Strategi Menghadapi Pelita VII). Kumpulan Makalah Semiloka Pra-Widyakarya Nasional Pangan dan Gizi. Semarang: Universitas Diponegoro; 1997; 1,15-16.

2. Satoto. Pertumbuhan dan Perkembangan Anak: Pengamatan Anak umur 0 - 18 Bulan di Kecamatan Mlonggo Kabupaten Jepara Jawa Tengah. Semarang: Universitas Diponegoro; 1990; 27,31.

3. Satoto. Reposisioning Pangan Sebagai Strategi KIE Penanggulangan Masalah Gizi Ganda. Kumpulan Makalah Semiloka Pra-Widyakarya Nasional Pangan dan Gizi. Semarang: Universitas Diponegoro; $1997 ; 2$.

4. Djalal F dan Atmojo SM. Gizi dan Kualitas Hidup: Agenda Perumusan Program Gizi Repelita VII Untuk Mendukung Pengembangan Sumber Daya Manusia Yang Berkualitas. Widyakarya Nasional Pangan dan Gizi VI. Jakarta; 1998; 222-223.

5. lyengar GV, Gopal-Ayengar AR. Human Health and Trace Elements; Effects on High Altitude Populations. 1988; (17): 31-35.

6. Anonimus. Hasil dan Rekomendasi Semiloka Antropometri di Indonesia. Ciloto, Jawa Barat; 1991; 2.

7. Muhilal, Djalal F, dan Hardinsyah. Angka Kecukupan Gizi Yang Dianjurkan. Kumpulan Makalah Semiloka PraWidyakarya Nasional Pangan dan Gizi. Semarang: Universitas Diponegoro; 1997; 25.

8. Dunn JT, Crutchfield HE, Gutekunst R, and Dunn AD. Methods for Measuring lodine in Urine. International Council for Control of lodine Deficiency Disorders. The Netherlands.1993.

9. WHO, UNICEF and ICCID. Indicators for Assesing lodine Defisiency Disorders and Their Control Through Salt lodization. Geneva.1994.

10. Cousin RJ. Zinc Metabolism: Coordinate Regulation As Related to Cellular Function. In TG Taylor and NK Jenkins (eds). Proceedings of the XIII International Conggress of Nutrition. . London and Paris: John Libbey; 1985. 
11. Hidayat A, Seng (Zinc) Esensial Bagi Kesehatan. Majalah IImiah Fakultas Kedokteran Trisakti. 1999:18(1): 2, 20.

12. Pudjiadi S. IImu Gizi Klinis Pada Anak. Jakarta: FKUI; 1990; 198, 203-204.

13. Linder MC (penerjemah Parakkasi). Biokimia Nutrisi dan Metabolisme. Jakarta: UI; 1992; 281.

14. WHO. Trace Elements In Human Nutrition and Health. Geneva; 1996; 41, 54-55, 58, 61, 75-76.

15. Ruz M, Codoceo J, Galgani J, Munoz L, and Bosco C. Single and Multiple Selenium-Zinc-lodine Deficiencies Affect Rat Thyroid Metabolism and Ultrastructure. J. Nutr 1999; 129: 174,177,179.

16. Guyton AC. Fisiologi Kedokteran. Jakarta: EGC; 1983; 5(2): 332-335,387-391, 440,458-463.

17. Brown JE. The Science of Human Nutrition. USA: Harcourt Brace Jovanovich. Inc; 1990; 335-336,338,340. 